\title{
Hubungan Keputusasaan dengan Depresi Pada Pasien Diabetes Melitus Di Padang
}

\author{
Rika Sarfika

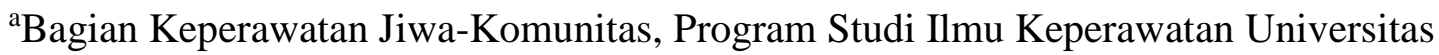 \\ Andalas, Padang, 25163, Indonesia \\ e-mail korespondensi : rikasarfika@nrs.unand.ac.id
}

\begin{abstract}
Diabetes mellitus is a chronic disease that can cause depression in sufferers. Depression is often associated with feelings of despair. This study aimed to investigate the relationship between hopelessness and depression among patients diabetes mellitus.This research is analytical research with a cross-sectional study approach. 122 people with type 2 diabetes mellitus at Pauh and Andalas Public health center were designated as samples in this study with inclusion criteria not having a history of mood disorders or mental disorders (based on medical diagnosis), aged 25 - 65 years and willing to sign an informed consent form. Data collection was conducted from September to October 2016 using the SDS (Self-rating Depression Scale) questionnaire and BHS (Beck Hopelessness Scale) questionnaire. Data were analyzed using the Chi-Square Test.There is a significant relationship between hopelessness and depression among diabetes mellitus patients $(P v=0.001)$. Patients with diabetes mellitus who experience despair have a risk of 7.03 times depression compared to patients who do not experience despair.Despair in patients with diabetes mellitus occurs due to negative thoughts about the disease in the future, lack of motivation in controlling blood sugar and negative expectations of the disease condition. These feelings make the patient depressed. Based on this, education needs to be given regarding diabetes mellitus and its treatment so that hopelessness can be anticipated.
\end{abstract}

Keywords: Diabetes mellitus, hopelessness, depression, adults, elderly

\begin{abstract}
Abstrak
Diabetes melitus merupakan penyakit kronik yang dapat menimbulkan depresi pada penderitanya. Depresi sering dikaitkan dengan perasaan keputusasaan. Tujuan penelitian ini mengetahui hubungan antara keputusaan dengan depresi pada pasien diabetes melitus. Jenis penelitian ini adalah penelitian analitik dengan pendekatan cross-sectional study. Sebanyak 122 orang pasien diabetes melitus tipe 2 di Puskesmas Pauh dan Puskesmas Andalas Padang ditetapkan sebagai sampel penelitian dengan kriteria inklusi tidak memiliki riwayat gangguan mood atau gangguan jiwa (berdasarkan diagnosis medis), berusia dalam rentang 25 sampai 65 tahun serta bersedia menandatangani informed consent. Pengumpulan data dilakukan pada bulan September sampai Oktober tahun 2016 dengan menggunakan kuesioner SDS (Selfrating Depression Scale) dan kuesioner BHS (Beck Hopelessness Scale). Data dianalisis menggunakan Uji Chi-Square.Ada hubungan yang signifikan antara keputusasaan dengan depresi pada pasien diabetes melitus $(\mathrm{P} v=0.001)$. Pasien diabetes melitus yang mengalami keputusasaan memilki resiko 7.03 kali terjadi depresi dibanding pasien yang tidak mengalami keputusasaan.
\end{abstract}


Saran: Keputusasaan pada pasien diabetes melitus terjadi karena pikiran negatif terhadap kondisi penyakit pada masa yang akan datang, kurangnya motivasi dalam pengontrolan gula darah serta harapan yang negatif terhadap kondisi penyakit. Perasaan-perasaan ini membuat pasien menjadi depresi. Berdasarkan hal ini, maka perlu diberikan edukasi mengenai diabetes melitus dan perawatannya agar keputusasaan dapat di antisipasi.

Keywords: Diabetes melitus, keputusasaan, depresi, dewasa, lansia

\section{PENDAHULUAN}

Diabetes Melitus merupakan salah satu penyakit kronik yang semakin mengkhawatirkan karena angkanya cenderung mengalami peningkatan setiap tahun. Prevalensi diabetes melitus secara global pada orang dewasa diperkirakan terus meningkat, dari 366 juta jiwa (8.3\%) di tahun 2010 meningkat menjadi 552 juta jiwa (9.9\%) di tahun 2030 (IDF, 2011). Di Indonesia, prevalensi diabetes melitus juga mengalami peningkatan. Data Riset Kesehatan Dasar (Riskesdas) menyatakan bahwa prevalensi diabetes melitus berdasarkan diagnosis dokter dari $1.1 \%$ di tahun 2007 meningkat menjadi $1.5 \%$ di tahun 2013 (Kemenkes RI, 2013), angka ini terus meningkat menjadi $2.0 \%$ di tahun 2018 (Kemenkes RI, 2018). Sementara, di provinsi Sumatera Barat sendiri juga terjadi peningkatan dari $0.7 \%$ ditahun 2007 menjadi $1.3 \%$ di tahun 2013 (Kemenkes RI, 2013), dan pada tahun 2018 meningkat lagi hingga mencapai $1.7 \%$ (Kemenkes RI, 2018). Data-data ini menggambarkan bahwa diabetes melitus masih menjadi permasalahan serius bagi Indonesia maupun Sumatera Barat.

Berbagai masalah psikososial dapat muncul pada penderita diabetes melitus antara lain yaitu depresi (Bădescu et al., 2016; Kok, Williams, \& Zhao, 2015). Diabetes juga dapat menyebabkan distress, gejala depresi, dan kualitas hidup menurun (Chew, Mohd-sidik, \& Shariff-ghazali, 2015). Selain itu, diabetes juga dapat menyebabkan kecemasan (Albekairy et al., 2018), stres (Joseph \& Golden, 2017) dan bahkan dapat muncul resiko bunuh diri pada penderita diabetes melitus (Conti et al., 2017).

Depresi merupakan masalah psikososial yang paling sering terjadi pada pasien diabetes melitus (Hsu et al., 2012; Kok et al., 2015). Sebanyak $87 \%$ penderita diabetes melitus mengalami depresi. (Khan, Lutale, \& Moledina, 2019). Penelitian Vuuren \& Pillay, (2019) mengungkapkan sebanyak $46,6 \%$ penderita diabetes melitus mengalami gangguan depresi mayor. Sementara hasil penelitian (Wang, Lopez, Bolge, Zhu, \& Stang, 2016) mengungkapkan bahwa kejadian depresi yang relevan secara klinis pada penderita diabetes melitus sebesar 10,6\% dan depresi signifikan secara klinis sebesar 4,2\%. Data ini menggambarkan bahwa penderita diabetes melitus memiliki resiko tinggi mengalami depresi

Depresi pada penderita diabetes dapat disebabkan oleh faktor genetik, biologis dan psikologis (Niraula, Kohrt, Flora et al., 2013; Khan et al., 2019) Menurut Holt, de Groot, \& Golden (2015), mekanisme dan patogenesis yang mendasari hubungan antara depresi dengan diabetes melitus adalah beban klinis dari penyakit, faktor gaya hidup dan kepatuhan, obat antidepresan, struktur dan fungsi otak, disfungsi aksis HPA, gangguan tidur, peradangan, dan faktor lingkungan. Holt et al (2015) mengungkapkan depresi pada klien diabetes melitus cenderung disebabkan oleh pengetahuan terhadap diagnosis, beban mengelola kondisi dan komplikasi penyakit. (Khan et al., 2019) juga mengungkapkan bahwa depresi terjadi karena ketidakpatuhan ketidakpatuhan terhadap pengobatan, kontrol metabolik yang buruk, tingkat komplikasi, penurunan 
kualitas hidup, perawatan yang dijalani dan biaya perawatan, peningkatan kecacatan dan kehilangan produktivitas, serta peningkatan risiko kematian. Faktor-faktor ini merupakan tanda dan gejala dari perilaku yang menggambarkan masalah keputusasaan.

Menurut kamus Standar Diagnostik Keperawatan Indonesia (SDKI), buruknya dalam aktivitas perawatan penyakit dan berpilaku pasif terhadap masalah kesehatan yang muncul merupakan tanda gejala dari keputusaasaan (PPNI, 2016). Teori keputusasaan-depresi mengungkapkan bahwa gejala-gejala perilaku dari keputusasaan-depresi adalah kurangnya motivasi, afek sedih, memiliki ide bunuh diri, kurang bertenaga, apatis, gangguan psikomotor, gangguan tidur, kosentrasi yang buruk, pikiran negatif yang diperburuk suasana hati (Abramson, Metalsky, \& Alloy, 1989). Berdasarkan latar belakang ini, maka penelitian ini bertujuan untuk melihat hubungan keputusasaan dengan depresi pada pasien diabetes mellitus.

\section{METODE}

Penelitian ini merupakan penelitian analitik dengan pendekatan cross-sectional study. Pengumpulan data depresi dan keputusasaan dilakukan peneliti sekaligus pada bulan September sampai dengan Desember 2016. Sebanyak 122 orang pasien diabetes melitus di wilayah kerja puskesmas Pauh dan puskesmas Andalas Padang yang memenuhi kriteria inklusi di ambil sebagai sampel penelitian melalui teknik purposive random sampling. Kriteria inklusi sampel yaitu pasien diabetes melitus tipe 2, berusia 25 sampai 65 tahun, kooperatif, menandatangani persetujuan menjadi sampel penelitian, dan pasien tidak memiliki riwayat gangguan mood atau riwayat gangguan jiwa. Cara pengumpulan data dengan memberikan kuesioner kepada pasien untuk mengukur keputusasaan dan depresi pada pasien.

Pengukuran kondisi depresi menggunakan kuesioner Self-rating Depression Scale (SDS) yang dikembangkan oleh Zung tahun 1965. Kuesioner ini terdiri 20 item pernyataan dengan skala likert $1-4$ (1= Jarang, dan $4=$ Selalu). Hasil ukur berupa tidak depresi (skor 20-49), depresi ringan (skor 50-69), dan depresi berat (skor 70-80). Hasil uji validitas dan reliabilitas terhadap kuesioner SDS pada 62 orang responden diabetes melitus didapatkan nilai cronbach's coefficient-alpha sebesar 0,837, artinya kuesioner ini valid dan reliabel dalam mengukur depresi pada pasien diabetes melitus. Sementara, alat ukur keputusasaan peneliti menggunakan kuesioner Beck Hopelessness Scale (BHS). Kuesioner ini terdiri dari 20 item pernyataan dengan skala Guftman "Ya/Tidak" ( $0=$ Ya, 1=Tidak). Kuesioner ini mengukur 3 aspek mayor gejala keputusasaan yakni perasaan tentang masa depan, motivasi yang menurun, dan harapan yang negatif atau positif terhadap kondisi penyakit. Hasil ukur berupa tidak putus asa (skor 0-3), keputusasaan ringan (skor 4-8), keputusasaan sedang (skor 914), dan keputusasaan berat (skor >15). Hasil uji validitas dan reliabilitas kuesioner BHS didapatkan nilai coefficient-alpha sebesar 0,766, artinya kuesioner ini valid dan reliabel dalam mengukur keputusasaan pada pasien diabetes melitus.

Selama proses penelitian, peneliti menerapkan prinsip etika penelitian yang terdiri dari Self-determination yaitu memberikan hak responden untuk tidak melanjutkan atau keluar dari penelitian tanpa memberikan dampak atau sanksi kepada responden. Kemudian peneliti juga menjaga Privacy responden selama penelitian, prinsip Anonymity dan Confidentiality dengan cara membuat insial responden saja. Selain itu, peneliti juga mencegah terjadinya perasaan tidak 
nyaman dan terluka (Protection from Discomfort and Harm) dengan cara menjelaskan maksud dan tujuan penelitian sebelum pengumpulan data dan meminta informed consent serta menggunakan alat ukur yang sudah valid dan reliabel.

Analisa data menggunakan sistem komputerisasi yang dilakukan melalui 2 tahapan yaitu analisa univariat dan analisa bivariat. Analisa univariat dilakukan untuk melihat distribusi frekuensi kondisi depresi dan keputusasaan serta karakteristik pasien diabetes mellitus. Sedangkan, analisa bivariat menggunakan uji Chi-Square yang bertujuan untuk melihat hubungan antara variabel keputusasaan dengan variabel depresi pada pasien diabetes melitus.

\section{HASIL}

\section{A. Gambaran karakteristik responden}

Tabel 1. Distribusi Frekuensi Karakteristik Responden $(\mathrm{n}=122)$

\begin{tabular}{|c|c|c|}
\hline Karakteristik & $f$ & $\%$ \\
\hline \multicolumn{3}{|l|}{ Jenis kelamin } \\
\hline - Laki-laki & 38 & 31.1 \\
\hline - Perempuan & 84 & 68.9 \\
\hline \multicolumn{3}{|l|}{ Usia } \\
\hline - Dewasa awal (26-35 tahun) & 2 & 1.6 \\
\hline - Dewasa akhir (36 - 45 tahun) & 14 & 11.5 \\
\hline - Lansia awal (46 - 55 tahun) & 31 & 25.4 \\
\hline - Lansia akhir (56 - 65 tahun) & 75 & 61.5 \\
\hline \multicolumn{3}{|l|}{ Pendidikan } \\
\hline - Rendah (SD-SMP) & 71 & 58.2 \\
\hline - Tinggi (SMA-PT) & 51 & 41.8 \\
\hline \multicolumn{3}{|l|}{ Pekerjaan } \\
\hline - Bekerja & 52 & 42.6 \\
\hline - Tidak bekerja & 70 & 57.4 \\
\hline \multicolumn{3}{|l|}{ Lama menderita DM } \\
\hline$-\leq 5$ tahun & 82 & 67.2 \\
\hline$->5$ tahun & 40 & 32.8 \\
\hline \multicolumn{3}{|l|}{ Riwayat pengobatan } \\
\hline - Terkontrol & 101 & 82.8 \\
\hline - Tidak terkontrol & 21 & 17.2 \\
\hline \multicolumn{3}{|l|}{ Ulkus } \\
\hline - Tidak ada ulkus & 107 & 87.7 \\
\hline - Ada ulkus & 15 & 12.3 \\
\hline \multicolumn{3}{|l|}{ Komplikasi } \\
\hline - Tidak ada komplikasi & 52 & 42.6 \\
\hline - Ada komplikasi & 70 & 57.4 \\
\hline
\end{tabular}

Tabel 1. mengungkapkan bahwa sebagian besar responden adalah pasien perempuan $(68.9 \%)$ dan sebagian besar berusia lansia akhir (61.5\%). Lebih separuh responden berpendidikan rendah dan tidak bekerja (57.4\%). Sebagian besar responden menderita penyakit diabetes melitus kurang dari 5 tahun (67.2\%) dengan riwayat pengobatan yang terkontrol $(82.2 \%)$ dan tidak ada ulkus $(87.7 \%)$ namun disertai dengan adanya komplikasi (57.4\%). Data mengenai karakteristik responden ini dapat dilihat pada Tabel 1.

\section{B. Gambaran Karakteristik Pasien Diabetes Melitus}

Tabel 2. Distribusi Frekuensi Depresi Berdasarkan Karakteristik Responden ( $\mathrm{n}=122)$

\begin{tabular}{|c|c|c|c|}
\hline \multirow{2}{*}{$\begin{array}{c}\text { Karakteristik } \\
\text { Responden }\end{array}$} & \multicolumn{3}{|c|}{ Kondisi Depresi } \\
\hline & $\begin{array}{c}\text { Tidak } \\
\text { depresi } \\
(\%)\end{array}$ & $\begin{array}{c}\text { Depresi } \\
\text { ringan } \\
(\%)\end{array}$ & $\begin{array}{c}\text { Total } \\
(\%)\end{array}$ \\
\hline \multicolumn{4}{|l|}{ 1. Jenis Kelamin } \\
\hline - Laki-laki & 18.9 & 12.3 & 31.1 \\
\hline - $\quad$ Perempuan & 37.7 & 31.1 & 68.9 \\
\hline \multicolumn{4}{|l|}{ 2. Usia } \\
\hline - Dewasa awal & 1.6 & 0 & 1.6 \\
\hline - Dewasa akhir & 8.2 & 3.3 & 11.5 \\
\hline - Lansia awal & 18.9 & 6.6 & 25.4 \\
\hline - Lansia akhir & 27.9 & 33.6 & 61.4 \\
\hline \multicolumn{4}{|l|}{ 3. Pendidikan } \\
\hline - Rendah (SD-SMP) & 25.4 & 32.8 & 58.2 \\
\hline - Tinggi (SMA-PT) & 31.1 & 10.7 & 41.8 \\
\hline \multicolumn{4}{|l|}{ 4. Pekerjaan } \\
\hline- Bekerja & 25.4 & 17.2 & 42.6 \\
\hline$-\quad$ Tidak Bekerja & 31.1 & 26.2 & 57.4 \\
\hline \multicolumn{4}{|l|}{ 5. Riwayat Pengobatan } \\
\hline$-\quad$ Terkontrol & 45.1 & 37.7 & 82.2 \\
\hline$-\quad$ Tidak terkontrol & 11.5 & 5.7 & 17.2 \\
\hline \multicolumn{4}{|l|}{ 6. Ulkus } \\
\hline - Tidak ada & 52.5 & 35.2 & 87.7 \\
\hline- Ada & 4.1 & 8.2 & 12.3 \\
\hline \multicolumn{4}{|l|}{ 7. Komplikasi } \\
\hline - Tidak ada & 35.2 & 7.4 & 42.6 \\
\hline- Ada & 21.3 & 36.1 & 57.4 \\
\hline \multicolumn{4}{|l|}{ 8. Lama menderita } \\
\hline$-\quad<5$ tahun & 39.3 & 27.9 & 67.2 \\
\hline$-\quad \geq 5$ tahun & 17.2 & 15.6 & 32.8 \\
\hline
\end{tabular}

Tabel 2. menunjukkan bahwa sebagian besar lansia akhir mengalami depresi (33.6 $\%$ dari $61.4 \%$ ), sebagian besar responden yang berpendidikan rendah mengalami depresi (32.8\% dari 58.2\%), sebagian besar pasien yang memiliki ulkus mengalami depresi (8.2\% dari 12.3\%), dan sebagian 
besar pasien yang memiliki komplikasi mengalami depresi (36.1\% dari $57.4 \%)$.

\section{Keputusasaan dan Depresi Pasien Diabetes Melitus}

Tabel 3. Distribusi Frekuensi Depresi dan Keputusasaan Responden ( $\mathrm{n}=122$ )

\begin{tabular}{|c|c|c|c|}
\hline \multirow{2}{*}{\multicolumn{2}{|c|}{ Variabel }} & \multicolumn{2}{|c|}{ Frekuensi } \\
\hline & & $\mathbf{n}$ & $\%$ \\
\hline \multicolumn{4}{|c|}{ 1. Depresi: } \\
\hline- & Tidak depresi & 69 & 56.6 \\
\hline- & Depresi ringan & 53 & 43.4 \\
\hline- & Depresi berat & 0 & 0.00 \\
\hline \multicolumn{4}{|c|}{ 2. $\quad$ Keputusasaan: } \\
\hline- & Tidak putus asa & 0 & 0.00 \\
\hline- & Keputusasaan ringan & 102 & 83.6 \\
\hline- & Keputusasaan sedang & 20 & 16.4 \\
\hline- & Keputusasaan berat & 0 & 0.00 \\
\hline
\end{tabular}

Tabel 3. Memperlihatkan bahwa hampir separuh pasien diabetes melitus mengalami depresi ringan $(43.4 \%)$ dan tidak ada pasien yang mengalami depresi berat. Sementara itu, pada masalah keputusasaan terdapat sebagian besar pasien mengalami keputusasaan ringan $(83.6 \%)$ dan yang lainnya mengalami keputusasaan sedang (16.4\%).

\section{Hubungan Keputusaan dengan Depresi pada Pasien Diabetes Melitus}

Tabel 4. Analisis Hubungan Keputusasaan dengan Depresi pada Pasien Diabetes Melitus

\begin{tabular}{|c|c|c|c|c|c|c|}
\hline \multirow{3}{*}{ Variabel } & \multicolumn{4}{|c|}{ Depresi } & \multirow{2}{*}{\multicolumn{2}{|c|}{ Total }} \\
\hline & \multicolumn{2}{|c|}{$\begin{array}{c}\text { Tidak } \\
\text { depresi }\end{array}$} & \multicolumn{2}{|c|}{$\begin{array}{c}\text { Depresi } \\
\text { ringan }\end{array}$} & & \\
\hline & $f$ & $\%$ & $f$ & $\%$ & $f$ & $\%$ \\
\hline Keputusasaan Ringan & 65 & 63.7 & 37 & 36.3 & 102 & 100 \\
\hline Keputusasaan Sedang & 4 & 20 & 16 & 80 & 20 & 100 \\
\hline CI 95\% & \multicolumn{6}{|c|}{$2.19-22.59$} \\
\hline OR & \multicolumn{6}{|r|}{7.03} \\
\hline $\mathrm{Pv}$ & \multicolumn{6}{|c|}{0.001} \\
\hline
\end{tabular}

Pada Tabel 4. terlihat hasil uji Chisquare menunjukkan terdapat hubungan yang signifikan antara keputusasaan dengan depresi pada pasien diabetes melitus (pValue: 0.001). Pasien diabetes melitus yang mengalami keputusasaan memiliki peluang sebanyak 7.03 kali mengalami depresi dibanding pasien diabetes yang tidak mengalami keputusasaan.

\section{PEMBAHASAN}

\section{Kondisi depresi pasien diabetes melitus}

Hasil penelitian memperlihatkan bahwa hampir dari separuh pasien diabetes melitus mengalami depresi ringan $(43.4 \%)$. Gejala-gejala depresi yang dialami oleh responden dalam penelitian ini berupa sering mengalami gangguan tidur, kadangkadang merasa hidup tidak bahagia lagi, kadang-kadang merasa sedih, sering tidak menjaga pola makan, sering merasa lelah, dan kadang-kadang berfikir untuk bunuh diri. Hal ini didukung oleh penelitian (Khan et al., 2019) bahwa sebagian besar responden diabetes mengalami depresi minimal $(56,7 \%), 22,1 \%$ depresi ringan, dan $8,2 \%$ mengalami depresi sedang.

Stuart (2013) mengungkapkan bahwa penyakit diabetes melitus merupakan penyakit kronik yang melemahkan tubuh yang dapat menyebabkan depresi pada penderitanya. Konsep ini juga diperkuat oleh Kaplan \& Saddock (2010) bahwa penyakit diabetes melitus dapat menimbulkan perubahan psikologi seperti perubahan proses mental, perilaku, dan fungsi neurologis sehingga menyebabkan klien menjadi pendiam, cemas, menarik diri, dan tidak aktif lagi dalam hubungan sosial. Hal ini merupakan tanda gejala seseorang mengalami depresi.

Banyak faktor yang dapat menyebabkan pasien diabetes melitus mengalami depresi, antara lain dapat disebabkan karena perubahan biokimia dalam tubuh penderita diabetes. Perubahan biokimia yang terjadi pada penderita diabetes melitus sama dengan perubahan yang terjadi pada depresi yaitu peningkatan hormon kortisol dan gangguan metabolisme epinefrin dan norepinefrin (Holt et al., 2015). Dalam penelitian ini ditemukan bahwa pasien yang memiliki 
komplikasi (misalnya hipertensi, jantung, dan lain-lain) mengalami depresi sebesar $62.9 \%$ dan sebagian besar pasien diabetes yang memiliki ulkus mengalami depresi sebesar $66.7 \%$ (lihat tabel 2). Peningkatan hormon kortisol, epinefrin, dan norepinefrin dipicu karena peningkatan kadar glukosa dalam darah sehingga pasien diabetes melitus mengalami gangguan mood seperti yang tampak pada gejala depresi. Terapi yang harus dilakukan secara rutin juga menimbulkan rasa bosan dan tertekan pada pasien yang mengakibatkan pasien merasa berbeda dengan orang lain dan akhirnya menimbulkan gejala depresi.

Hasil penelitian ini menemukan bahwa sebagian besar pasien diabetes melitus mengeluh nafsu makan berkurang, tidak bergairah melakukan hubungan seksual, sulit berfikir jernih dan mengambil keputusan, sulit menemukan solusi untuk menyelesaikan masalah, tidak bergairah dalam melakukan aktivitas kehidupan. Price \& Wilson (2006) mengungkapkan bahwa pasien diabetes melitus akan cenderung mengalami tiga gejala khas (tripoli) yaitu poliuria, polidipsi, dan polifagia. Poliuria menyebabkan pasien merasakan gatal-gatal disekitar daerah kemaluan dan akhirnya dapat menimbulkan infeksi pada daerah tersebut, hal ini tentu membuat pasien merasa tidak nyaman, tidak punya motivasi untuk melakukan hubungan seksual serta merasa malu terhadap pasangan sehingga menimbulkan rasa cemas, sedih, tidak berharga dan malu terhadap pasangan. polidipsi menyebabkan rasa haus yang semakin sering dan polifagia menyebabkan rasa lapar karena glukosa banyak dikeluarkan bersama urine sehingga hal ini menyebabkan klien sering mengeluh lelah, lemah, gangguan tidur dan berat badan menurun. Tanda dan gejala psikologi yang diakibatkan oleh manifestasi klinis ini merupakan tanda dan gejala depresi.
Tabel 3. memperlihatkan bahwa lebih dari separuh responden tidak mengalami depresi (56.6\%), kurang dari separuh responden mengalami depresi ringan $(43.4 \%)$ dan tidak ada responden yang mengalami depresi berat. Ini berarti, pasien diabetes melitus dalam penelitian ini belum mengalami masalah psikologis yang berarti. Hasil penelitian ini didukung oleh penelitian Yonzon, Joshi, \& Ghimire (2018) bahwa proporsi responden diabetes yang mengalami depresi sebesar $29.2 \%$. Namun, penelitian Vuuren \& Pillay (2019) mengungkapkan hal yang berbeda yaitu sebesar $46,6 \%$ pasien diabetes melitus mengalami gangguan depresi mayor. Hasil penemuan ini bertentangan dengan konsep depresi dan penyakit kronik. Hal ini dapat disebabkan karena kondisi klinis pasien yang dilibatkan dalam penelitian ini tidak dalam kondisi buruk seperti yang terlihat dalam tabel 1 bahwa sebagian besar responden tidak memiliki ulkus $(87.7 \%)$ dan lebih dari separuh responden menderita diabetes melitus kurang dari 5 tahun (67.2\%). Selain itu, pasien memiliki manajemen perawatan diri yang bagus yang ditandai dengan sebagian besar mereka memiliki riwayat pengobatan yang terkontrol (82.8\%). Meskipun pada tabel 1 menunjukkan lebih separuh responden memiliki komplikasi (57.4\%), tetapi ini tidak bisa menjadi patokan tingkat keparahan kondisi klinis yang dialami responden karena komplikasi dalam penelitian ini tidak berdasarkan diagnosis dokter. Komplikasi ini hanya berdasarkan persepsi dan gejala yang dirasakan responden. Akan tetapi, pada Tabel 2 memperlihatkan bahwa kecenderungan terjadinya depresi pada pasien diabetes melitus yang memiliki riwayat pengobatan yang terkontrol dengan yang tidak terkontrol hampir sama.

Selain kondisi klinis penyakit dan manajemen perawatan, faktor kareakteristik juga dapat mempengaruhi terjadinya depresi pada pasien diabetes melitus. Tabel 2 memperlihatkan bahwa 
perempuan lebih cenderung mengalami depresi dibanding laki-laki dengan prevalensi masing-masing sebesar $45,1 \%$ dan $39.5 \%$. Hasil penemuan ini didukung oleh Penelitian (Khan et al., 2019) yaitu prevalensi depresi lebih tinggi pada perempuan $64 \%$ sedangkan pada laki-laki 35,1\%. Pada tabel 1 juga terlihat sebagian besar pasien diabetes melitus adalah berusia lanjut (56 - 65 tahun) yaitu sebanyak $61.4 \%$ dan prevalensi depresi pada usia ini yang terlihat pada tabel 2 adalah sebesar 54.7\%. Sementara prevalensi depresi pada usia dewasa akhir sebesar $28.7 \%$ dan lansia awal sebesar $26 \%$. Ini berarti, individu lanjut usia atau disebut dengan lansia akhir memiliki resiko yang lebih tinggi mengalami depresi dibanding usia lain. Hal ini juga diungkapkan oleh Trief (2007) bahwa semakin tua usia maka semakin berpotensi mengalami diabetes melitus. Resiko terkena diabetes melitus pada usia 65 sampai dengan 74 tahun diperkirakan menjadi tiga kali lipat, sedangkan pada usia 75 tahun keatas menjadi 5 kali lipat. Hasil penelitian juga menunjukkan bahwa pasien diabetes yang berpendidikan rendah (SD-SMP) memiliki prevalensi depresi yang lebih besar dibanding pasien diabetes yang berpendidikan tinggi dengan prevalensi masing-masing yaitu $56.4 \%$ dan $25.6 \%$ (tabel 2).

\section{Keputusasaan Pada Pasien Diabetes Melitus}

\footnotetext{
Hasil penelitian menunjukkan mayoritas pasien diabetes melitus mengalami keputusasaan ringan $(83.6 \%)$, sebagian kecil pasien diabetes melitus mengalami keputsasaan sedang (16.4\%), dan tidak ada pasien yang mengalami keputusasaan berat (tabel 3). Hasil penelitian ini membuktikan bahwa semua pasien mengalami keputusasaan, meskipun hanya berada pada level ringan sampai sedang. Hal ini dapat terjadi karena diabetes melitus merupakan penyakit kronik degeneratif yang membutuhkan
}

ketelatenan dalam mengontrol gula darah sepanjang hidup pasien namun kekambuhan-kekambuhan juga terjadi sehingga hal ini menimbulkan perasaan keputusasaan pada pasien.

Perasaan keputusasaan yang terjadi pada pasien dalam penelitian ini dapat dipengaruhi karena faktor usia dan komplikasi. Lebih dari separuh responden dalam penelitian ini adalah lansia akhir $(61.5 \%)$ dan lebih dari separuh responden memiliki komplikasi (57.4\%) (lihat tabel 1). Rata-rata pada pasien lansia akhir memiliki sikap pasrah dan tidak antusias melakukan pengobatan karena menganggap penyakit adalah karena usia dan tidak bisa disembuhkan. Hal ini diperkuat oleh Liu, et al bahwa orang tua dan orang yang memiliki penyakit lebih cenderung mengalami keputusasaan dan menghasilkan tingkat depresi yang tinggi (Liu, Kleiman, Nestor, \& Cheek, 2016).

Dalam penelitian ini ditemukan keluhan-keluhan pasien seperti tidak ada harapan, menyerah, berfikir negatif terhadap status kesehatan pada masa selanjutnya, tidak punya masa depan yang cerah atau masa depan yang gelap, merasa selalu gagal dan pengorbanan yang sia-sia, sedih dan tidak antusias meningkatkan kesehatan. Menurut kamus MerriamWebster's Collegiate Dictionary keputusasaan adalah kata benda yang terkait dengan kata sifat harapan. Menjadi putus asa berarti menjadi sedih, putus asa, dan sedih, atau menghadapi situasi yang tidak mungkin, tidak dapat disembuhkan, atau tidak dapat diperbaiki (Dunn, 2005). Dalam American Psychiatric Association's (APA) Diagnostic and Statistical Manual of Mental Disorders (DSM IV-TR) (American Psychiatric As- sociation, 2000) menjelaskan bahwa keputusasaan adalah pesimisme yang meluas tentang masa depan. Dalam perspektif psikologis, keputusasaan adalah harapan dari hasil negatif dan ketidakberdayaan (Abramson et al., 1989). Sedangkan dari perspektif 
kognitif, Beck et al. (1974) keputusasaan adalah harapan negatif dan ketidakberdayaan dari hasil yang negatif yang dilihat dari tiga dimensi yakni dimensi kognitif, dimensi afektif dan dimensi motivasi. Dimensi kognitif terdiri dari harapan masa depan yang negatif, seperti pemikiran yang mencakup masa depan yang gelap atau tidak pasti. Dimensi afektif terdiri dari perasaan negatif tentang masa depan, termasuk kurangnya harapan, antusiasme, atau keyakinan. Dimensi motivasi mencakup pikiran dan perasaan negatif tentang kemampuan seseorang untuk mengubah atau meningkatkan kesejahteraan masa depan.

Perasaan keputusasaan yang dirasakan pasien dapat dikaitkan dengan kualitas hidup yang dipersepsikan oleh pasien tersebut. Pasien yang menggambarkan kondisinya baik maka kecil kemungkinan mengalami perasaan keputusasaan, begitu juga sebaliknya jika pasien menggambarkan kondisinya tidak baik maka besar kemungkinan terjadinya perasaan keputusaasaan pada pasien. Pasien diabates melitus memiliki distress, depresi dan kualitas hidup yang buruk yang disebabkan oleh keterbatasan fisik, gejala klinis dan gejala emosional yang dialami (Chew et al., 2015). Hasil penelitian menemukan pasien yang mengalami keputusasaan cenderung akan pasrah dengan kondisinya karena sulit disembuhkan, sulit mengambil keputusan, dan pesimis dengan masa depan. 90,2\% pasien menganggap bahwa penyakit diabetes melitus tidak dapat disembuhkan, 94,3\% pasien merasa tidak ada harapan untuk masa depan, 94,3\% pasien merasa tidak bahagia terhadap masa depan, dan sebanyak $83,6 \%$ pasien menganggap tidak ada gunanya melakukan upaya untuk kesembuhan penyakit karena penyakit tidak bisa disembuhkan. Hal ini tentu berbahaya jika dibiarkan karena dapat memperburuk kondisi diabetes melitus pasien.

\section{Hubungan Keputusasaan Dengan Depresi}

Berdasarkan hasil penelitian yang telah dilakukan terdapat hubungan yang signifikan antara keputusasaan dengan depresi pada pasien diabete melitus $(\mathrm{P} v=$ 0.001). Hasil uji chi-square didapatkan nilai OR sebesar 7.03, yang artinya pasien diabetes melitus yang mengalami keputusasaan memiliki peluang sebanyak 7.03 kali mengalami depresi dibanding pasien diabetes yang tidak mengalami keputusasaan (tabel 4). Pasien diabetes melitus yang memiliki keputusasaan ringan mengalami depresi ringan sebesar $36.3 \%$, sedangkan pasien yang memiliki keputusasaan sedang mengalami depresi ringan sebesar $80 \%$ (tabel 4). Salah satu rantai kausal penyebab depresi adalah keputusasaan. Interaksi antara gaya kognitif dan peristiwa kehidupan negatif akan menimbulkan rasa keputusasaan. Kekambuhan yang berulang-ulang atau kondisi yang tidak berubah dapat mencetuskan munculnya rasa keputusasaan pada pasien dan selanjutnya keputusasaan ini akan menimbulkan depresi pada pasien (Kim, Linton, Cho, \& Ha, 2016).

Teori hopelessness dalam Abramson et al., (1989) menjelaskan bahwa "an expectancy that positive consequences will not occur, or that negative consequences will occur" , yang artinya adalah harapan bahwa konsekuensi positif tidak akan terjadi atau konsekuensi negatif akan terjadi. Orang yang mengalami keputusasaan akan merasa tidak ada harapan untuk mewujudkan suatu yang diinginkan atau setiap apa yang dilakukan tidak akan berhasil menyelesaikan masalah. Dalam penelitian ini, sebagian besar pasien merasa tidak memiliki harapan untuk menatap masa depannya yang lepas dari penyakit diabetes yang dia alami saat ini dan hampir separuh dari mereka menyatakan menyerah dengan 
kondisi sekarang karena merasa tidak ada yang bisa dilakukan selain hanya pasrah dengan penyakitnya.

Keputusasaan juga dianggap sebagai model diatesis stress depresi. Peristiwa kehidupan yang negatif berfungsi sebagai "occasion setters" dimana peristiwa negatif tersebut dapat menimbulkan depresi bagi individu yang memiliki sifat inferensial negatif (Liu et al., 2016). Hasil penelitian ini mengungkapkan bahwa sebagian besar pasien diabetes melitus yang depresi, merasakan ketidaknyamanan menjalani kehidupannya saat ini, merasa sudah lelah melakukan perawatan namun merasa siasia untuk merubah kehidupan.

Keputusasaan menjadi sebuah alasan dalam hambatan pengobatan. Dengan adanya rasa putus asa, perasaan pesimis dan merasa tidak bisa sehat akan menimbulkan stres dan dapat mengakibatkan gejala depresi (Liu et al., 2016). Hasil penelitian ini mengungkapkan bahwa kegagalan pada pengalaman sebelumnya membuat pasien merasa tidak ada harapan untuk memperbaiki status kesehatannya saat ini. Pikiran negatif ini merupakan suatu bentuk keputusasaan yang di alami pasien. Selanjutnya dengan pikiran negatif ini menimbulkan ketidakpatuhan pada pasien dalam perawatan misalnya dengan melanggar diet dan pola istirahat.

\section{KESIMPULAN DAN SARAN}

Hasil penelitian ini menunjukkan ada hubungan yang signifikan antara keputusasaan dengan depresi pada pasien diabetes melitus. Pasien diabetes melitus yang mengalami keputusasaan beresiko 7,03 kali mengalami depresi dibanding pasien yang tidak mengalami keputusasaan. Hasil penelitian ini memberikan saran kepada perawat sebagai tenaga kesehatan profesional harus memberikan layanan kesehatan secara utuh yaitu tidak hanya memperhatikan aspek fisik saja namun juga aspek psikososial kedua aspek ini saling berkaitan dan saling mempengaruhi keberhasilan kepatuhan pasien terhadap perawatan penyakitnya. Memberikan edukasi mengenai diabetes dan perawatan diabetes serta memberikan terapi kognitif-perilaku sangat disarankan dalam penelitian ini dengan tujuan untuk mencegah keputusasaan yang diakibatkan kurangnya pengetahuan dan pikiran serta persepsi negatif terhadap penyakit. Selanjutnya, perlu penelitian selanjutnya yang berkaitan dengan terapi yang tepat untuk mencegah keputusasaan pada pasien diabetes melitus yang mengalami depresi.

\section{UCAPAN TERIMA KASIH}

Penelitian ini merupakan penelitian hibah Fakultas Keperawatan Universitas Andalas pada Skim Penelitian Dosen Muda pada tahun 2016 dengan nomor kontrak 108/XIII/D/FKEP/2016.

\section{DAFTAR PUSTAKA}

Abramson, L. Y., Metalsky, G. I., \& Alloy, L. B. (1989). Hopelessness Depression: A Theory-Based Subtype of Depression. Psychological Review, 96 (2), 358-372. https://doi.org/10.1037/0033295X.96.2.358

Albekairy, A., Aburuz, S., Alsabani, B., Alshehri, A., Aldebasi, T., Alkatheri, A., \& Almodaimegh, H. (2018). Exploring factors associated with depression and anxiety among hospitalized patients with type 2 diabetes mellitus. Medical Principles and Practice, 26(6), 547-553. https://doi.org/10.1159/000484929

Balitbang Kemenkes, RI. (2013). Riset Kesehatan Dasar (Riskesdas 2013).

Bădescu, S., Tătaru, C., Kobylinska, L., Georgescu, E., Zahiu, D., Am, Z., \& Zăgrean, L. (2016). The association between Diabetes mellitus and 
Depression Pathophysiological mechanisms. Journal of Medicine and Life, 9(2), 120-125.

Balitbang Kemenkes RI (2018). Hasil Utama RISKESDAS 2018.

Chew, B., Mohd-sidik, S., \& Shariffghazali, S. (2015). Negative effects of diabetes - related distress on healthrelated quality of life: an evaluation among the adult patients with type 2 diabetes mellitus in three primary healthcare clinics in Malaysia. Health and Quality of Life Outcomes. https://doi.org/10.1186/s12955-0150384-4

Conti, C., Mennitto, C., Di Francesco, G., Fraticelli, F., Vitacolonna, E., \& Fulcheri, M. (2017). Clinical characteristics of diabetes mellitus and suicide risk. Frontiers in Psychiatry,8(MAR),1-7. https://doi.org/10.3389/fpsyt.2017.0004 0

Dunn, S. L. (2005). Hopelessness as a response to physical illness. Journal of Nursing Scholarship, 37(2), 148-154. https://doi.org/10.1111/j.15475069.2005.00027.x

Holt, R. I. G., de Groot, M., \& Golden, S. H. (2015). Diabetes and Depression. HHS Public Access: Author Manuscript, $\quad 14(6), \quad 491$. https://doi.org/10.1007/s11892-0140491-3.Diabetes

Hsu, Y. M., Su, L. T., Chang, H. M., Sung, F. C., Lyu, S. Y., \& Chen, P. C. (2012). Diabetes mellitus and risk of subsequent depression: A longitudinal study. International Journal of Nursing Studies, 49(4), 437-444. https://doi.org/10.1016/j.ijnurstu.2011.0 9.019

International Diabetes Federation. (2011). IDF Diabetes Atlas 5th edition. Media. https://doi.org/10.1007/978-90-4813271-3

Joseph, J. J., \& Golden, S. H. (2017). Cortisol dysregulation: the bidirectional link between stress, depression, and type 2 diabetes mellitus. Annals of the
New York Academy of Sciences, 1391(1), 20-34. https://doi.org/10.1111/nyas.13217

Kaplan, \& Saddock. (2010). Buku Ajar Psikiatri Klinis (2nd ed.). Jakarta: EGC.

Khan, Z. D., Lutale, J., \& Moledina, S. M. (2019). Prevalence of Depression and Associated Factors among Diabetic Patients in an Outpatient Diabetes Clinic. Psychiatry Journal, 2019.

Kim, B. J., Linton, K., Cho, S., \& Ha, J. H. (2016). The relationship between neuroticism, hopelessness, and depression in older Korean immigrants. PLoS ONE, 11(1), 1-10. https://doi.org/10.1371/journal.pone.014 5520

Kok, J. L. A., Williams, A., \& Zhao, L. (2015). Psychosocial interventions for people with diabetes and co-morbid depression. A systematic review. International Journal of Nursing Studies, 52(10), 1625-1639. https://doi.org/10.1016/j.ijnurstu.2015.0 5.012

Liu, R. T., Kleiman, E. M., Nestor, B. A., \& Cheek, S. M. (2016). The Hopelessness Theory of Depression: A Quarter Century in Review. HHS Public Access, 22(4),345-365. https://doi.org/10.1111/cpsp.12125.The

PPNI. (2016). Standar Diagnosis Keperawatan Indonesia: Definisi dan Indikator Diagnostik. (Tim Pokja SDKI DPP PPNI, Ed.) (1st ed.). Jakarta: DPP PPNI.

Price, S., \& Wilson, L. (2006). Patofisiologi: Konsep Klinis Prosesproses Penyakit (6th ed.). Jakarta: EGC.

Stuart, G. W. (2013). Principles and Practice of Psyciatric Nursing (10th ed.). St. Louis, Missouri: Mosby Elsevier.

Trief, P. M. (2007). Depression in Elderly Diabetes Patients. Diabetes Spectrum, 20(2),

$71-75$. https://doi.org/10.2337/diaspect.20.2.71

Vuuren, J. M. J. Van, \& Pillay, S. (2019). Major depressive disorder in patients with diabetes mellitus in 
NERS: Jurnal Keperawatan, Volume 15, No. 1, Maret 2019, (Hal. 14-24)

Pietermaritzburg, South Africa. SAMJ, 109(1), 2017-2020. https://doi.org/10.7196/SAMJ.2019.v10 9i1.13356

Wang, Y., Lopez, J. M. S., Bolge, S. C., Zhu, V. J., \& Stang, P. E. (2016). Depression among people with type 2 diabetes mellitus, US National Health and Nutrition Examination Survey ( NHANES ), $2005-$ 2012. BMC Psychiatry, 1-16. https://doi.org/10.1186/s12888-0160800-2

Yonzon, P., Joshi, A., \& Ghimire, M. (2018). Prevalence of Depression among Nepalese Patients with Type 2 Diabetes Attending Endocrine Clinic in Kathmandu, Nepal. DIABETES, 67(1). https://doi.org/doi.org/10.2337/db182259-PU 